\title{
Phosphine-catalysed reductive coupling of Dihalophosphanes
}

Jan-Erik Siewert, ${ }^{[a]}$ André Schumann ${ }^{[a]}$ and Christian Hering-Junghans ${ }^{*[a]}$

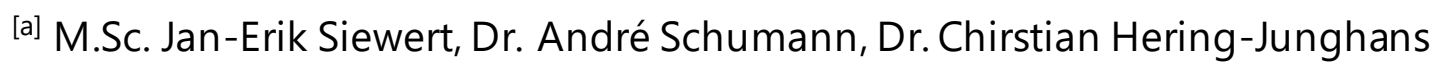

Leibniz Institute of Catalysis e.V. Rostock (LIKAT)

Albert-Einstein-Straße 29a, 18059 Rostock, Germany

E-Mail: christian.hering-junghans@catalysis.de

\begin{abstract}
Classically, tetraorgano diphosphanes have been synthesized through Wurtz-type reductive coupling of halophosphanes $\mathrm{R}_{2} \mathrm{PX}$ or more recently, through the dehydrocoupling of phosphines $\mathrm{R}_{2} \mathrm{PH}$. Catalytic variants of the dehydrocoupling reaction have been reported but are limited to $\mathrm{R}_{2} \mathrm{PH}$ compounds. Using $\mathrm{PEt}_{3}$ as a catalyst, we now show that $\operatorname{TipPBr}_{2}\left(\mathrm{Tip}=2,4,6-i \mathrm{Pr}_{3} \mathrm{C}_{6} \mathrm{H}_{2}\right.$ ) is selectively coupled to give the dibromodiphosphane (TipPBr $)_{2}(\mathbf{1})$, a compound not accessible using classic Mg reduction. Surprisingly, when using $\operatorname{DipPBr}_{2}\left(\operatorname{Dip}=2,6-i \mathrm{Pr}_{3} \mathrm{C}_{6} \mathrm{H}_{3}\right)$ in the $\mathrm{PEt}_{3}$-catalysed reductive coupling the diphosphene $(\mathrm{PDip})_{2}(\mathbf{2})$ with a $\mathrm{P}=\mathrm{P}$ double was formed selectively. In benzene solutions (PDip) 2 has a half life-time of ca. 28 days and can be utilized with NHCs to access NHC-phosphinidene adducts. Control experiments show that $\left[\mathrm{BrPEt}_{3}\right] \mathrm{Br}$ is a potential oxidation product in the catalytic cycle, which can be then debrominated by using $\mathrm{Zn}$ dust as sacrificial reductant.
\end{abstract}

\section{Introduction}

The formation of element-element bonds in main group chemistry is still dominated by classic stoichiometric salt metathesis and reductive coupling reactions. Only in 
recent years, catalytic protocols for the dehydrocoupling of main group ( $p$-block) substrates to species with homonuclear $(E-E)$ or heteronuclear $\left(E-E^{\prime}\right)$ bonds have emerged. ${ }^{1-3}$ Catalysis with earth-abundant metals, in particular $\mathrm{Zr}$, $\mathrm{Fe}$ and $\mathrm{Ni}^{4}$ has been shown to be a viable alternative to using rather expensive systems based on $\mathrm{Rh}^{5-7} \mathrm{Ir}^{7-}$ ${ }^{10}$ and Ru. ${ }^{11}$ Using main-group species to facilitate the homo- or heterocoupling of $\mathrm{p}$ block elements has also been in the focus of current research.

Among potential coupling products, diphosphanes have received attention as both synthetic targets as well as undesired by-products, for example in the synthesis of tertiary phosphines. ${ }^{12-17}$ Diphosphanes have also been shown to readily react with alkenes and alkynes to give diphos-type ligands. ${ }^{13}$ Classically, tetraorganodiphosphanes have been synthesized through Wurtz-type reductive coupling of $\mathrm{R}_{2} \mathrm{PCl}$ using various metals ( $\mathrm{Li}, \mathrm{Na}, \mathrm{K}, \mathrm{Mg}$ and $\mathrm{Hg}$ ) (Scheme 1, I). ${ }^{18-21}$ Alternatively, chlorophosphanes react with simple phosphines $\mathrm{HPR}_{2}$ to give $\mathrm{R}_{2} \mathrm{P}_{-}-\mathrm{PR}_{2}$ under $\mathrm{HCl}$ elimination (Scheme 1, II), ${ }^{22}$ which can be enhanced by the addition of tertiary amines. ${ }^{23}$

Established routes towards Tetraorgano-Diphosphanes:
(I) $\left(\mathrm{Me}_{2} \mathrm{~N}\right)_{2} \mathrm{PCl}+2 \mathrm{Na} \underset{-2 \mathrm{NaCl}}{\stackrel{\longrightarrow}{-}}\left(\mathrm{Me}_{2} \mathrm{~N}\right)_{2} \mathrm{P}-\mathrm{P}\left(\mathrm{NMe}_{2}\right)_{2}$
Wurtz-type
reductive coupling
(II)
$\mathrm{Ph}_{2} \mathrm{PCl}+\mathrm{HPPh}_{2} \underset{-\mathrm{HCl}}{\longrightarrow}$
$\mathrm{Ph}_{2} \mathrm{P}-\mathrm{PPh}_{2}$
Dehydrochlorination
(III) $2 \mathrm{Ph}_{2} \mathrm{PH}$
cat. or
$\stackrel{\mathrm{H}_{2} \text {-acceptor }}{\longrightarrow} \mathrm{Ph}_{2} \mathrm{P}-\mathrm{PPh}_{2}$
Dehydrocoupling

Classic Synthesis of Diphosphenes:

$(\mathrm{VI})$

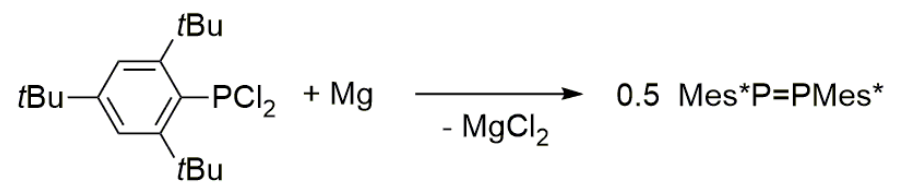

Scheme 1. Synthetic pathways (I-III) towards $R_{2} P-P R_{2}, R(X) P-P(X) R(I V, V)$ and diphosphenes (VI). 
Another viable pathway is the salt metathesis between $\mathrm{R}_{2} P C l$ and $\mathrm{R}_{2} \mathrm{PLi}$, which can be improved by $\mathrm{BH}_{3}$-stabilization of the lithium phosphide. ${ }^{13,24}$ The dehydrocoupling of $\mathrm{HPR}_{2}$ (Scheme 1, III), ${ }^{25-27}$ chlorosilane elimination from $\mathrm{R}_{2} \mathrm{PSiMe}_{3}$ and $\mathrm{R}_{2} \mathrm{PCl}$ or $\mathrm{P}-\mathrm{N} / \mathrm{P}-\mathrm{P}$ bond metathesis reactions are other synthetic pathways described in the literature. ${ }^{28-}$ 29

The lack of transition metal catalysed dehydrocoupling reactions of $\mathrm{R}_{2} \mathrm{PH}$ giving diphosphanes can be most likely attributed to catalyst deactivation by unproductive phosphine coordination. However, $\mathrm{Zr}-_{-}{ }^{30} \mathrm{Fe}_{-},{ }^{31}$ and $\mathrm{Rh}$-based ${ }^{32}$ metal complexes have been successfully used in the catalytic dehydrocoupling of phosphines to make P-P bonds. $^{1,33}$ Just recently, $t$ BuOK was shown to efficiently catalyse the dehydrocoupling of phosphines using imines or azobenzene as a hydrogen acceptor. ${ }^{34}$ In comparison to tetraorgano-diphosphanes, diorgano-dihalo-diphosphanes of the type $R(X) P-P(X) R$ are rare $(X=C l, B r, I)$. The stoichiometric reduction of $\left(\left(\mathrm{Me}_{3} \mathrm{Si}\right)_{2} \mathrm{~N}_{2}\left(\mathrm{SiMe}_{3}\right)\right) \mathrm{PCl}_{2}$ with $\mathrm{Cp}_{2} \mathrm{Ti}(\mathrm{btmsa}) \quad\left(\right.$ btmsa $\left.=\mathrm{C}_{2}\left(\mathrm{SiMe}_{3}\right)_{2}\right)$ in a 2:1 ratio, yielded the corresponding dichlorodiphosphane $\mathrm{R}(\mathrm{Cl}) \mathrm{P}-\mathrm{P}(\mathrm{Cl}) \mathrm{R}\left(\mathrm{R}=\mathrm{N}\left(\mathrm{SiMe}_{3}\right) \mathrm{N}\left(\mathrm{SiMe}_{3}\right)_{2}\right.$, Scheme 1, IV $) .{ }^{35} \mathrm{Ph}(\mathrm{Br}) \mathrm{P}-$ $\mathrm{P}(\mathrm{Br}) \mathrm{Ph}$ was obtained by reduction of $\mathrm{PhPBr}_{2}$ with $\mathrm{Mg}$ metal in $80 \%$ yield and was shown to reversibly disproportionate in solution giving (PPh) ${ }_{5}$ and $\mathrm{PhPBr}_{2}$ (Scheme 1, V). ${ }^{36}$ Another class of $\mathrm{P}-\mathrm{P}$ bonded species are the diphosphenes, ${ }^{37}$ comprising a $\mathrm{P}=\mathrm{P}$ double bond and the first variant, Mes ${ }^{*}=$ PMes $^{*}\left(\mathrm{Mes}^{*}=2,4,6-t \mathrm{Bu}_{3} \mathrm{C}_{6} \mathrm{H}_{3}\right)$, was synthesized through the reductive coupling of $\mathrm{Mes}^{*} \mathrm{PCl}_{2}$ with $\mathrm{Mg}$ metal (Scheme 1, $\mathrm{VI}){ }^{38}$ Since its initial discovery in the early 1980's diphosphenes have emerged as a well-studied class of compounds and alternative synthetic pathways, ${ }^{37}$ including the dimerization of phospha-Wittig reagents upon loss of $\mathrm{PMe}_{3}$ have been established. ${ }^{39}$ Even though a large variety of diphosphenes is known, sterically demanding and therefore kinetically stabilizing groups attached to phosphorus are needed to stabilize the reactive $\mathrm{P}=\mathrm{P}$ double bond, as formation of larger oligomers, namely cyclooligophosphanes is observed otherwise. ${ }^{40-41}$

Our group has shown that aryldihalophosphanes of the type $\operatorname{ArPX}_{2}(\operatorname{Ar}=2,4,6$ $\mathrm{Me}_{3} \mathrm{C}_{6} \mathrm{H}_{3}$, Mes; 2,6-i $\mathrm{Pr}_{2} \mathrm{C}_{6} \mathrm{H}_{3}$, Dip; 2,4,6-i $\mathrm{Pr}_{3} \mathrm{C}_{6} \mathrm{H}_{2}$, Tip; $\mathrm{X}=\mathrm{Cl}, \mathrm{Br}$ ) are selectively coupled 
using a mixture of $\mathrm{PMe}_{3}$ and $\mathrm{Zn}$ to give the corresponding triphosphiranes $(\mathrm{PAr})_{3} . \mathrm{PMe}_{3}$ was identified as the active reductant..$^{42}$ By using $\mathrm{PMe}_{3} \mathrm{Cl}_{2}{ }^{43}$ and $\mathrm{Zn}$ as the sacrificial reductant in the reaction with $\mathrm{TipPCl}_{2}$ we demonstrated that (PTip) ${ }_{3}$ is the major product formed. This is in line with the seminal work of Sisler on the reductive coupling of chlorophosphines with trialkylphosphines. ${ }^{44-46}$ Moreover, we noticed the formation of the diphosphene TipP=PTip when $\mathrm{TipPBr}_{2}$ was reacted with 1.3 equiv of $\mathrm{PEt}_{3 .}{ }^{42} \mathrm{This}$ raised the question whether catalytic amounts of $\mathrm{PR}_{3}(R=\mathrm{Me}, \mathrm{Et})$ will facilitate the reductive coupling of $\mathrm{ArPX}_{2}$.

\section{Results and Discussion}

In this study we focused on two $\operatorname{ArPBr}_{2}(\mathrm{Ar}=\mathrm{Dip}, \mathrm{Tip})$ derivatives. As a first entry we revisited the reduction of $\mathrm{TipPBr}_{2}$ with $\mathrm{PEt}_{3}$. $\mathrm{PEt}_{3}$ was chosen, as we expected a higher solubility of the oxidation product $\left[\mathrm{PBr}_{4}\right] \mathrm{Br}_{1}{ }^{47-48}$ compared to the insoluble by-product when $\mathrm{TipPCl}_{2}$ was reduced with $\mathrm{PMe}_{3}{ }^{42}$ At first THF was selected as solvent in conjunction with $20 \mathrm{~mol}^{2} \mathrm{PEt}_{3}$ as the catalyst and 3 equiv zinc dust and the reaction mixture was analysed by ${ }^{31} \mathrm{P}$ NMR spectroscopy after stirring $1 \mathrm{~h}$ at $-78{ }^{\circ} \mathrm{C}$. This revealed the formation of diphosphane $(\mathrm{TipPBr})_{2}(\mathbf{1})$ in $36 \%$ as a diastereomeric mixture, namely the meso- and rac-compounds, with $64 \%$ of unconverted $\mathrm{TipPBr}_{2}$ (Table 1, entry 1). Better conversion into (TipPBr) 2 (77 \%) was noted when the mixture was stirred at room temperature for $1 \mathrm{~h}$ under otherwise same conditions (Table 1, entry 2). However, continued stirring at ambient temperature for $16 \mathrm{~h}$ afforded a mixture of (PTip) ${ }_{3}$ and (PTip) ${ }_{4}$ and also minimal amounts of the diphosphene (PTip) 2 were detected (Table 1, entry 3). Lowering the amount of PEt $\mathrm{t}_{3}$ to $10 \mathrm{~mol} \%$ in THF after $1 \mathrm{~h}$ at room temperature a conversion of $\mathrm{TipPBr}_{2}(54 \%)$ into 1 of $46 \%$ was detected. Increasing the reaction time to $3 \mathrm{~h}$ the conversion into 1 increased to $69 \%$. Using these conditions 1 (Table 1, entry 5) was isolated as yellow crystalline solid after evaporation of the volatiles and extraction of the crude mixture with toluene. Concentration to 
incipient crystallization and storage at $-78{ }^{\circ} \mathrm{C}$ for $48 \mathrm{~h}$ gave 1 as a yellow crystalline solid in moderate, yet reproducible yields of ca. $30 \%$. Further decreasing the catalyst loading to $5 \mathrm{~mol} \%$, full conversion could not be achieved even after 16h (Table 1 , entries 6 and 7). It needs to be noted that the formation of (PTip) $)_{3}$ and (PTip) ${ }_{4}$ was not detected when using 10 or 5 mol\% of $\mathrm{PEt}_{3}$, respectively. This clearly shows the potential of $\mathrm{PEt}_{3}$ to act as a catalyst for the reductive coupling of halophosphines, giving the diphosphane $(\mathrm{TipPBr})_{2}(\mathbf{1})$ rather selectively.

Even though, the crystalline material of $\mathbf{1}$ seemed to be uniform, testing different crystals revealed that both $R, S-\mathbf{1}$ (meso) and S,S-1 (rac) crystallize next to each other. Dissolving the isolated crystals of 1 in $\mathrm{C}_{6} \mathrm{D}_{6}$ indicates that a 4.7:1 ratio between the two forms is still present in solution, as indicated by two signals at 65.4 and $64.4 \mathrm{ppm}$ in ${ }^{31} \mathrm{P}$ NMR spectrum, respectively (Figure S25).

Table 1. Screening different amounts of $\mathrm{PEt}_{3}$ in the catalytic coupling of $\mathrm{TipPBr}_{2}$ in $\mathrm{THF}$ after different reaction times using $\mathrm{Zn}$ dust as a sacrificial reductant.

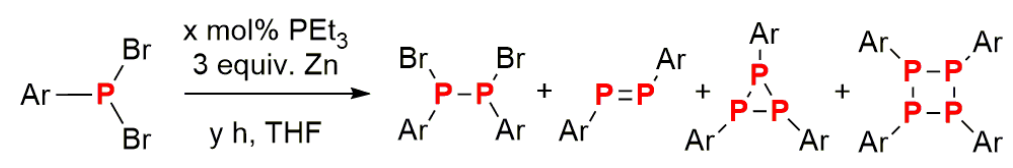
A
B
C
D $\quad$ E

\begin{tabular}{l|l|l|l|l|l|l|l|l}
\hline Entry & $\mathbf{P E t}_{\mathbf{3}}$ [mol\%] & $\mathbf{T}\left[{ }^{\circ} \mathbf{C}\right]$ & $\mathbf{t}[\mathbf{h}]$ & $\mathbf{A}^{\mathbf{a}}$ & $\mathbf{B}^{\mathbf{a}}$ & $\mathbf{C}^{\mathbf{a}}$ & $\mathbf{D}^{\mathbf{a}}$ & $\mathbf{E}^{\mathbf{a}}$ \\
\hline 1 & 20 & -78 & 1 & 64 & 36 & 0 & 0 & 0 \\
3 & 20 & r.t. & 1 & 23 & 77 & 0 & 0 & 0 \\
4 & 10 & r.t. & 16 & 0 & 0 & 36 & 41 & 23 \\
5 & 10 & r.t. & 1 & 54 & 46 & 0 & 0 & 0 \\
6 & 5 & r.t. & 3 & 31 & 69 & 0 & 0 & 0 \\
7 & 5 & r.t. & 1 & 100 & 0 & 0 & 0 & 0 \\
\hline
\end{tabular}

${ }^{a}$ Conversion determined by ${ }^{31} \mathrm{P}$ NMR spectroscopy, normalized to $\mathbf{A}$, duplicate runs. 
In the ${ }^{1} \mathrm{H}$ NMR the expected 2:1 ratio between the $o$ - and $p$-iPr groups was found. However, one of the two forms shows rather featureless, broad signals, thereby precluding a clean assignment in both, the ${ }^{1} \mathrm{H}$ and ${ }^{13} \mathrm{C}$ NMR spectrum. The purity of the bulk material was established by $\mathrm{CHN}$ analysis.

$R, S-1$ and $S, S-1$ crystallize in the triclinic space group $P-1$ with one inversion symmetric molecule in the case of $R, S-\mathbf{1}$ and two molecules in the unit cell in $S, S-\mathbf{1}$, respectively (Figure 1). In $R, S-1$ the bromine atoms are arranged in trans fashion across the P-P bond $[2.2402(8) \AA] \quad\left(\sum r_{\text {cov }}(\mathrm{P}-\mathrm{P})=2.22 \AA_{1}^{49} \quad c f . \quad(\mathrm{R}(\mathrm{Cl}) \mathrm{P})_{2} \quad \mathrm{R}=\mathrm{N}_{2}\left(\mathrm{SiMe}_{3}\right)_{3} \quad d(\mathrm{P}-\mathrm{P})\right.$ $2.255(1) \AA)_{1}^{35}$ with the phosphorus atoms being in a trigonal pyramidal coordination environment [ $\Sigma(<P) 303.4^{\circ}$ ] (Figure 1, left). In S,S-1 the bromine atoms are arranged in cis fashion on the same side of the P-P bond [2.2382(6) $\AA$ ] with a dihedral $\mathrm{Br}-\mathrm{P}-\mathrm{P}-\mathrm{Br}$ angle of 55.2(2) (Figure 1, right).
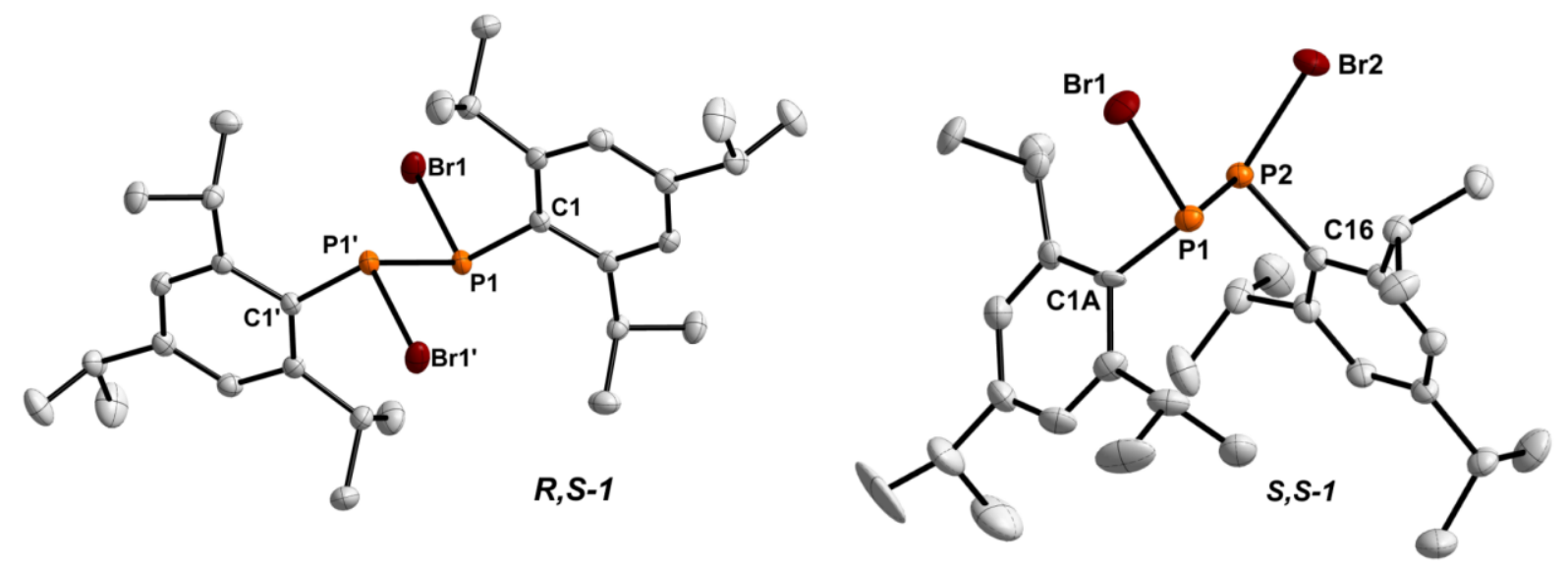

Figure 1. Molecular structures of 1. Hydrogen atoms have been omitted for clarity. Thermal ellipsoids are drawn at the $50 \%$ probability level. Selected bond lengths $(\AA)$ and angles $\left(^{\circ}\right) R, S-1: P 1-P 1{ }^{\prime} 2.2402(8)$, $\mathrm{P} 1-\mathrm{C} 1$ 1.8337(15), P1-Br1 2.2592(4); C1-P1-Br1 105.94(5), C1-P1-P1' 102.10(5), P1'-P1-Br1 95.36(2). S,S-1 P1-P2 2.2382(6), P1-Br12.2512(4), P2-Br22.2478(5);C1A-P1-Br1 104.2(4), P2-P1-Br1 103.243(19), C1A-P1-P2 92.1(4).

Next, $\mathrm{DipPBr}_{2}$ was employed as a substrate and to our surprise the diphosphane (DipPBr) $)_{2}$ was not formed using $10 \mathrm{~mol}_{0}$ of $\mathrm{PEt}_{3}$ as a catalyst at room temperature. Instead, the major species detected in the ${ }^{31} \mathrm{P}$ NMR spectrum after stirring for $3 \mathrm{~h}$ showed a significantly deshielded signal at $513.0 \mathrm{ppm}$ (Scheme 2, top). This hinted at 
the formation of the diphosphene (PDip) ${ }_{2}\left(c f .(\mathrm{PTip}){ }_{2} \delta\left({ }^{31} \mathrm{P}\left\{{ }^{1} \mathrm{H}\right\}\right)=517.4 \mathrm{ppm}\right){ }_{1}^{42}$ which was confirmed by SC-XRD experiments on crystals grown from a saturated $n$-hexane solution at $-30{ }^{\circ} \mathrm{C}$. Using the same conditions that allowed the isolation of $1(10 \mathrm{~mol} \%$ $\mathrm{PEt}_{3,}, 3$ equiv $\mathrm{Zn}$ dust, THF, 3 h), 2 was isolated in reproducible yields of ca. $30 \%$ in the form of yellow crystals. It needs to be noted that the direct reduction of $\mathrm{DipPBr}_{2}$ with one equivalent magnesium turnings gave the triphosphirane (PDip) ${ }_{3}$ as the major product (Figure S22). Using half an equivalent of $\mathrm{Mg}$ full conversion was not achieved after $3 \mathrm{~h}$ with ( $\mathrm{DipPBr})_{2}$ being formed in ca. $20 \%$ yield in rather unselective fashion (Figure S23). The formation of $\mathbf{2}$ is remarkable, as usually aryl groups with a greater steric profile are needed to stabilize diphosphenes, vide infra. Alternatively, thermodynamic stabilization of diphosphenes can be achieved by using amino functions on phosphorus, however, dimerization to the corresponding cyclotetraphosphanes has been described for $\left[\left(\mathrm{Me}_{3} \mathrm{Si}\right)_{2} \mathrm{NP}_{2} .{ }^{50}\right.$

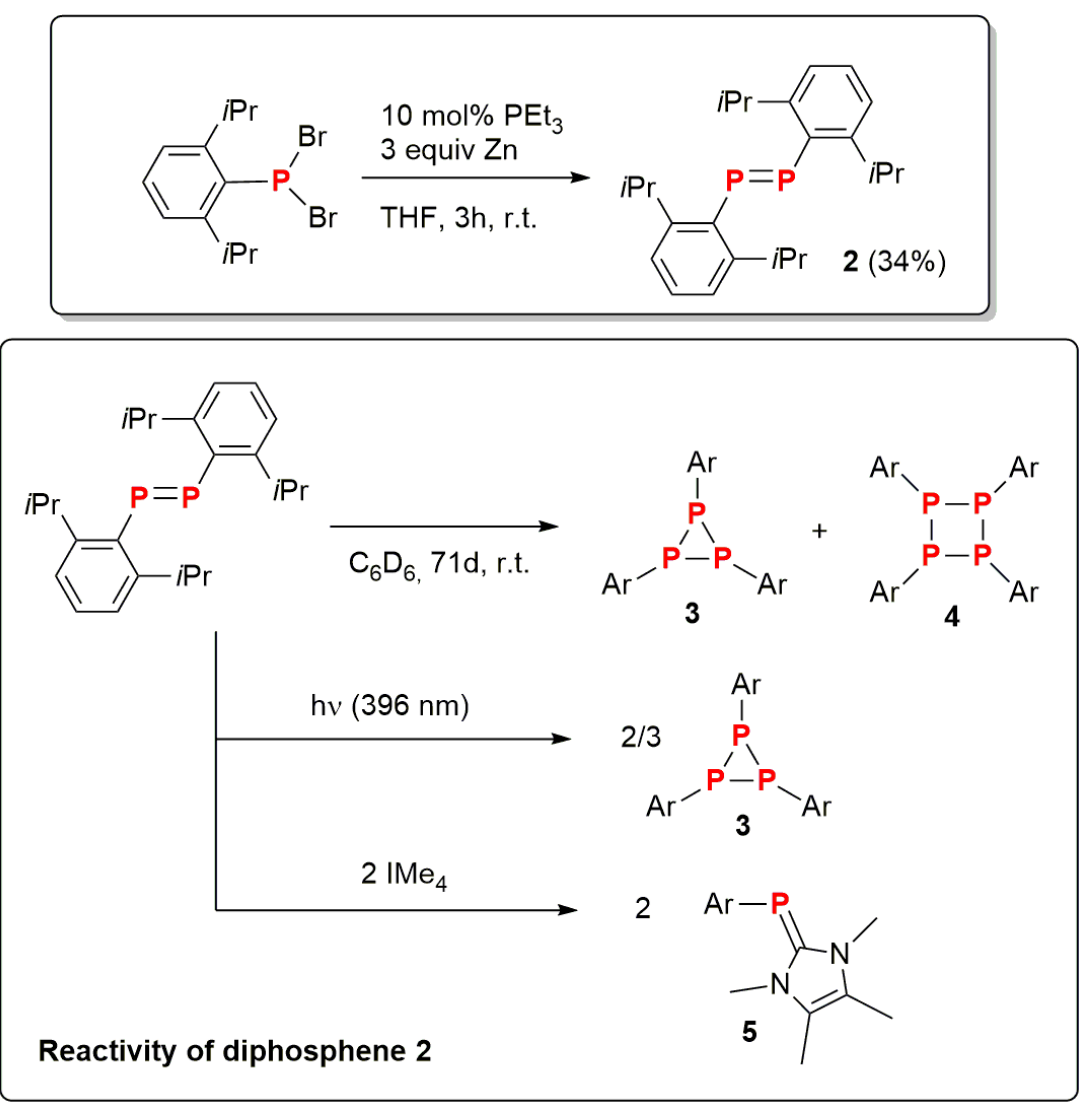

Scheme 2. Synthesis of diphosphene (PDip) $)_{2}$ (2) (top) and its reactivity (bottom). 
2 crystallizes in the triclinic space group $P$ - 1 with one inversion symmetric molecule in the unit cell (Figure 2). The Dip-substituents are arranged in trans fashion with the P-P bond $[2.0293(7) \AA]$ in the expected range for diphosphenes $\left[c f .\left({ }^{(\mathrm{Pr} 4} \mathrm{CpP}\right)_{2}\right.$ 2.0282(10) $\AA] . .^{51}$ The C-P-P angles [99.59(4) ${ }^{\circ}$ ] are narrower compared to (Mes*P) ${ }_{2}[c f$. $\left.102.8(1)^{\circ}\right]$ in agreement with the lesser steric demand of the Dip-substituent compared to Mes*. To determine the kinetic stability of $\mathbf{2}$, a solution in $\mathrm{C}_{6} \mathrm{D}_{6}$ was kept at room temperature under the exclusion of light and was monitored over a period of $71 \mathrm{~d}$ (Figures S32-33, Table S4). The half-life time of $\mathbf{2}$ is ca. $28 \mathrm{~d}$, which is considerably more stable than $\left[\left(\mathrm{Me}_{3} \mathrm{Si}\right)_{2} \mathrm{C}(\mathrm{H}) \mathrm{P}\right]_{2}$ with a half-life time of ca. $7 \mathrm{~d}$ at room temperature, ${ }^{52}$ or the ruby red liquid $\left[\left(\mathrm{Me}_{3} \mathrm{Si}_{2}\right)_{2} \mathrm{NP}_{2}\right.$ which in isolated form dimerizes to the corresponding cyclo-tetraphosphane within hours. ${ }^{50}$ The thermal decomposition products have been shown to be the triphosphirane (PDip) $)_{3}(3)$ and the dimerization product (PDip) ${ }_{4}(\mathbf{4})$ in a 3:1 ratio. Irradiation of 2 with an $\operatorname{LED}(\lambda=396 \mathrm{~nm})$ resulted in the immediate and clean formation of 3, which was corroborated by UV-Vis studies (Scheme 2, Figures S35-37). The yellow colour of 2 stems from a HOMO- 1 and HOMO-3 to LUMO $\left(\pi-\pi^{\star}\right)$ transition according to TD-DFT calculations on the PBE0-D3/def2-TZVP level of theory (Table S7, Figure S48).



Figure 2. Molecular structure of 2. Hydrogen atoms have been omitted for clarity. Thermal ellipsoids are drawn at the $50 \%$ probability level. Selected bond lengths $(\AA)$ and angles $\left(^{\circ}\right)$ : P1-P1' 2.0293(7), P1-C1 1.8471(10); C1-P1-P1' 99.59(4), C2-C1-P1-P1' 91.75(8). 
The cyclic voltammogram of 2 in $\operatorname{THF}\left(0.1 \mathrm{M}\left[n \mathrm{Bu}_{4} \mathrm{~N}\right]\left[\mathrm{PF}_{6}\right]\right)$ showed a reversible reduction event at $-2.10 \mathrm{~V}$ (vs. $\mathrm{Cp}_{2} \mathrm{Fe} / \mathrm{Cp}_{2} \mathrm{Fe}^{+}$; Figure S31), which is higher than that of $\left(\mathrm{Mes}^{*} \mathrm{P}\right)_{2}(-2.36 \mathrm{~V}){ }_{1}^{53}$ and $\left.([\mathrm{sB}] \mathrm{P})_{2}(-2.24 \mathrm{~V})[\mathrm{sB}]=\left(\mathrm{H}_{2} \mathrm{CNDip}\right)_{2} \mathrm{~B}\right)^{54}$ suggesting a lower LUMO level in $\mathbf{2}$ compared to these species. With compound $\mathbf{2}$ accessible we became interested in its reactivity towards $\mathrm{N}$-heterocyclic carbenes (NHCs). Jana and coworkers have recently shown reversible NHC binding to $\left({ }^{\text {Mes } T e r P}\right)_{2}\left({ }^{\text {Mes Ter }}=2,6-(2,4,6-\right.$ $\left.\left.\mathrm{Me}_{3} \mathrm{C}_{6} \mathrm{H}_{2}\right)-\mathrm{C}_{6} \mathrm{H}_{3}\right)_{1}^{55}$ whereas Matsuo et al. showed cleavage of the $\mathrm{P}=\mathrm{P}$ bond in (RIND $P)_{2} \quad$ (RIND = 1,1,3,3,5,5,7,7-octa-R-substituted s-hydrindacen-4-yl) to give $\mathrm{NHC}$ phosphinidene adducts. ${ }^{56}$ Combination of $\mathbf{2}$ with two molar equiv of $\mathrm{IMe}_{4}$ $\left(\mathrm{IMe}_{4}=(\mathrm{MeCNMe})_{2} \mathrm{C}:\right)$ resulted in the formation of $\mathrm{DipP}=\mathrm{IMe}_{4}(\mathbf{5})$, which was isolated in pure form in $50 \%$ yield after recrystallization from saturated $n$-hexane solutions at $-30{ }^{\circ} \mathrm{C} .5$ shows a characteristic ${ }^{31} \mathrm{P}\left\{{ }^{1} \mathrm{H}\right\}$ NMR signal at -86.3 ppm (cf. EINDP=IMe 4 $\left.\delta\left({ }^{31} \mathrm{P}\right)=-63.9 \mathrm{ppm}\right)$ and one set of signals for the iPr-groups for the Dip group in the expected 1:6 ratio and two signals for Me-groups of $\mathrm{IMe}_{4}$ in a 1:1 ratio, indicating $C_{\mathrm{s}}$ symmetry in solution. 5 crystallizes in the monoclinic spacegroup $P 2_{1} / n$ with four molecules in the unit cell. The $P-C_{N H C}$ distance [1.7730(13) $\AA$ ] agrees with the formulation as an inversely polarized phosphaalkene (cf.EIND-PIMe 4 1.767(3) A, Figure 3). ${ }^{56-57}$

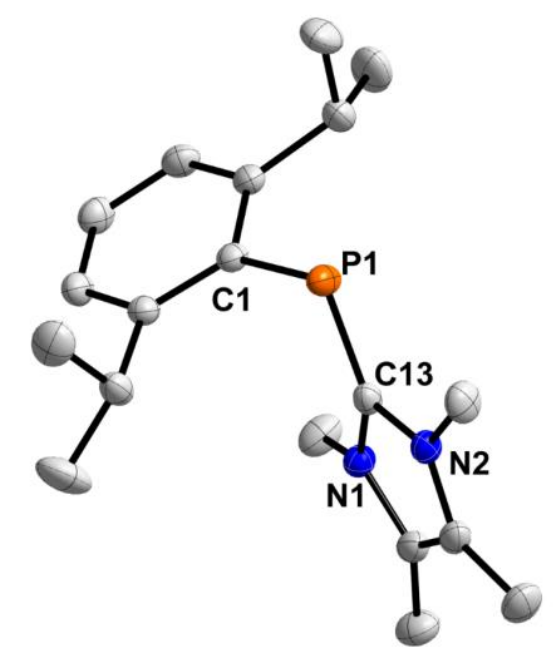

Figure 3. Molecular structure of 5. Hydrogen atoms have been omitted for clarity. Thermal ellipsoids are drawn at the 50\% probability level. Selected bond lengths $(\AA)$ and angles $\left({ }^{\circ}\right)$ : P1-C1 1.8490(12), P1-C13 1.7730(13); C1-P1-C13 103.60(5), C13-P1-C1-C6 66.95(11). 
Attempts to prepare metal complexes of $\mathbf{2}$ proved unsuccessful, however, we noted the dimerization of $\mathbf{2}$ to give cyclo-tetraphosphane $\mathbf{4}$ as the main product in the presence of one molar equivalent of $\mathrm{PdCl}_{2}$. This allowed to isolate some colourless crystals of $\mathbf{4}$ and its molecular structure was determined by means of X-Ray crystallography (Figure S44).

Control experiments were carried out to better understand this trialkylphosphinecatalysed coupling of dibromophosphanes. Using the corresponding dichlorophosphanes $\mathrm{DipPCl}_{2}$ and $\mathrm{TipPCl}_{2}$ under optimized conditions, the formation of the dichlorodiphosphanes $(\mathrm{ArPCl})_{2}$ was observed after $3 \mathrm{~h}$ in $\mathrm{THF}$, however, conversions lack behind those observed for the dibromophosphanes. We then tested whether $\left[\mathrm{BrPEt}_{3}\right] \mathrm{Br}$ can be used to generate $\mathrm{PEt}_{3}$ in the presence of $\mathrm{Zn}$ in THF. When employing $10 \mathrm{~mol} \%\left[\mathrm{BrPEt}_{3}\right] \mathrm{Br}$ with $\mathrm{DipPBr}$, the starting material was mostly consumed after $3 \mathrm{~h}$ and a nearly equimolar mixture of diphosphane (DipPBr) 2 and (PDip) $)_{3}$ was obtained (Figure S7). Similarly, half of $\mathrm{TipPBr}_{2}$ is converted into 1 using $\left[\mathrm{BrPEt}_{3}\right] \mathrm{Br}$ as the catalyst. This clearly underlines that $\left[\mathrm{BrPEt}_{3}\right] \mathrm{Br}$ is a potential oxidation product, however, the formation of $\left[\mathrm{Et}_{3} \mathrm{PPEt}_{3}\right] \mathrm{Br}_{2}$ cannot be excluded, as diphosphonium salts were shown to be formed upon reduction of $\mathrm{Sb}(\mathrm{OTf})_{3}$ with $\mathrm{PR}_{3}(\mathrm{R}=\mathrm{Me}, \mathrm{Et}) .{ }^{58}$ Using $\mathrm{PMe}_{3}(10 \mathrm{~mol} \%, 2$ equiv $Z n$ ) as a catalyst $\mathrm{DipPBr}_{2}$ was coupled to give (DipPBr) ${ }_{2}$ and (PDip) $)_{3}$ in a 2:1 ratio and $\operatorname{DipPBr}_{2}$ was fully consumed after $3 \mathrm{~h}$, however, attempts to isolate (DipPBr) 2 have proven unsuccessful to date. In contrast, with $\mathrm{TipPBr}_{2}$ and $10 \mathrm{~mol} \%$ of $\mathrm{PMe}_{3}$ a $1: 1$ mixture of $\operatorname{TipPBr}_{2}$ and $\mathbf{1}$ was detected. To identify $\mathrm{Zn}$ as the sacrificial reductant both $\mathrm{TipPBr}_{2}$ and $\mathrm{DipPBr}_{2}$ were stirred over an excess of $\mathrm{Zn}$ dust in the absence of $\mathrm{PEt}_{3}$ and no conversion was observed (Scheme 3, reaction i) after $3 \mathrm{~h}$ at room temperature. When only using 10 mol\% of $\mathrm{PEt}_{3}$ without adding $\mathrm{Zn}$ dust in the coupling of $\mathrm{TipPBr}_{2}$ and $\mathrm{DipPBr}_{2}$ only $10 \%$ of the starting material was converted into 1 (Scheme 3, reaction ii). In light of these observations we propose a catalytic cycle in which in a first ste $p$ $\mathrm{ArPBr}_{2}$ is coupled to give 1 ( $\mathrm{Ar}=$ Tip) with concomitant formation of $\left[\mathrm{BrPEt}_{3}\right] \mathrm{Br}$, which is then reduced by zinc to regenerate $\mathrm{PEt}_{3}$ (Scheme 3, top). The formation of $\mathbf{2}$ is surprising and in this case the intermediate formation of DipP $=\mathrm{PEt}_{3}$, which then reacts 
with a second equivalent of $\mathrm{DipPBr}{ }_{2}$ under $\mathrm{P}=\mathrm{P}$ bond formation to give $\mathbf{2}$ and $\left[\mathrm{BrPEt}_{3}\right] \mathrm{Br}$, which can then enter the catalytic cycle again, seems plausible. In this regard it worth noting that $\mathrm{PMe}_{3}$ and $\mathrm{PnBu}_{3}$ have both been shown to catalyse the chlorine atom transfer between $\mathrm{ArPPMe}_{3}$ and $\mathrm{Ar}^{\prime} \mathrm{PCl}_{2}$ to give $\mathrm{ArPCl}_{2}$ and $\mathrm{Ar}^{\prime} \mathrm{PPMe}_{3}{ }^{59}$

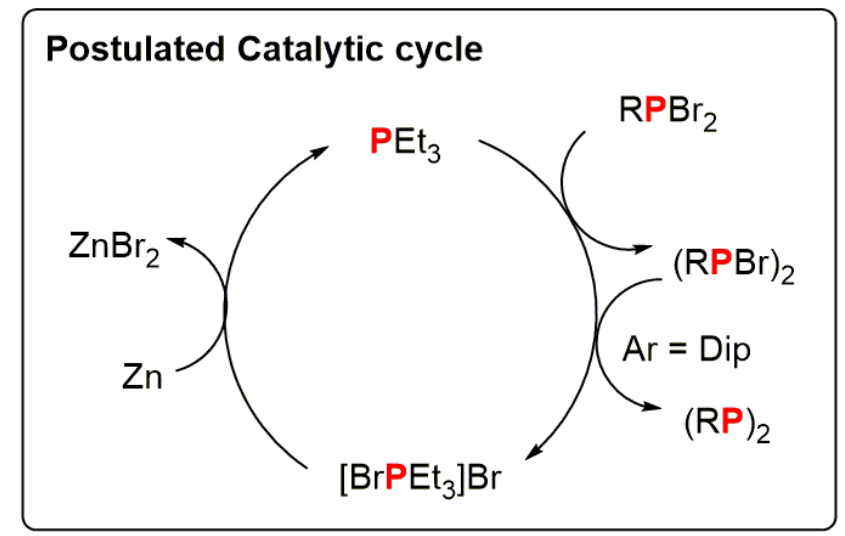

Control experiments:

(i) $\mathrm{TipPBr}_{2}+$ exc. $\mathrm{Zn}$ no reaction

(ii) $\mathrm{TipPBr}_{2} \underset{\mathrm{THF}, 3 \text {, r.t. }}{\stackrel{10 \mathrm{~mol}_{0}\left[\mathrm{BrPEt}_{3}\right] \mathrm{Br}}{\longrightarrow}} \begin{gathered}(\mathrm{TipPBr})_{2} \\ (10 \% \text { conversion })\end{gathered}$ 1

Scheme 3. Proposed catalytic cycle and control experiments to determine the role of $\mathrm{Zn}$ and $\mathrm{PEt}_{3}$.

\section{Conclusion}

Even though limited in scope, we have shown that simple $\mathrm{PEt}_{3}$ catalyses the coupling of dibromophosphanes, to give a rare example of an aryl-substituted dibromodiphosphane in $\mathbf{1}$ or the diphosphene 2 . Control experiments have shown that $\left[\mathrm{BrPEt}_{3}\right] \mathrm{Br}$ is one of the oxidations products and zinc powder acts as a sacrificial reductant to regenerate $\mathrm{PEt}_{3}$. Diphosphene 2 has a half-life time of ca. $28 \mathrm{~d}$ decomposing cleanly to give (PDip) $n(n=3,4)$. When irradiated at $396 \mathrm{~nm} 2$ cleanly converts into (PDip) ${ }_{3}$. The addition of $\mathrm{NHC} \mathrm{IMe}_{4}$ to 2 afforded the corresponding NHC 
phosphinidene adduct 5. Furthermore 2 dimerizes in the presence of $\mathrm{PdCl}_{2}$ to give the corresponding cyclo-tetraphosphane (DipP $)_{4}(\mathbf{4})$. In future studies we will look to further extend the scope of this catalytic protocol to make this an invaluable tool for $E-E$ bond formation reactions beyond the formation $\mathrm{P}-\mathrm{P}$ bonded species.

\section{Acknowledgements}

This research was funded by the Leibniz Association within the scope of the Leibniz ScienceCampus Phosphorus Research Rostock (www.sciencecampus-rostock.de). We thank our technical and analytical staff for assistance, especially Dr. Anke Spannenberg for her support regarding X-ray analysis. We also wish to thank the ITMZ at the University of Rostock for access to the Cluster Computer and especially Malte Willert for technical support.

\section{Conflicts of interest}

There are no conflicts to declare.

\section{Electronic Supplementary Information (ESI)}

Electronic Supplementary Information (ESI) available: Synthesis and characterization of compounds, NMR and IR spectra, crystallographic, and computational details. CCDC 2098825-2098829 contain the supplementary crystallographic data for this paper. These data can be obtained free of charge via www.ccdc.cam.ac.uk/data_request/cif, or by emailing data_request@ccdc.cam.ac.uk, or by contacting The Cambridge Crystallographic Data Centre, 12 Union Road, Cambridge CB2 1EZ, UK; fax: +44 1223 336033. 


\section{Notes and References}

1. Greenberg, S.; Stephan, D. W., Stoichiometric and catalytic activation of P-H and P-P bonds. Chem. Soc. Rev. 2008, 37 (8), 1482-1489.

2. Waterman, R., Dehydrogenative Bond-Forming Catalysis Involving Phosphines. Curr. Org. Chem. 2008, 12 (15), 1322-1339.

3. Han, D.; Anke, F.; Trose, M.; Beweries, T., Recent advances in transition metal catalysed dehydropolymerisation of amine boranes and phosphine boranes. Coord. Chem. Rev. 2019, 380, 260-286.

4. Kaniewska, K.; Dragulescu-Andrasi, A.; Ponikiewski, Ł.; Pikies, J.; Stoian, S. A.; Grubba, R., Syntheses, Structures and Reactivity of Terminal Phosphido Complexes of Iron(II) Supported by a $\beta$-Diketiminato Ligand. Eur. J. Inorg. Chem. 2018, 2018 (38), 4298-4308.

5. Dorn, H.; Singh, R. A.; Massey, J. A.; Nelson, J. M.; Jaska, C. A.; Lough, A. J.; Manners, I., Transition Metal-Catalyzed Formation of Phosphorus-Boron Bonds: A New Route to Phosphinoborane Rings, Chains, and Macromolecules. J. Am. Chem. Soc. 2000, 122 (28), 6669-6678.

6. Choffat, F.; Käser, S.; Wolfer, P.; Schmid, D.; Mezzenga, R.; Smith, P.; Caseri, W., Synthesis and Characterization of Linear Poly(dialkylstannane)s. Macromolecules 2007, 40 (22), 7878-7889.

7. Johnson, H. C.; Leitao, E. M.; Whittell, G. R.; Manners, I.; Lloyd-Jones, G. C.; Weller, A. S., Mechanistic Studies of the Dehydrocoupling and Dehydropolymerization of Amine-Boranes Using a [Rh(Xantphos)] ${ }^{+}$Catalyst. J. Am. Chem. Soc. 2014, 136 (25), 9078-9093.

8. Staubitz, A.; Sloan, M. E.; Robertson, A. P. M.; Friedrich, A.; Schneider, S.; Gates, P. J.; Schmedt auf der Günne, J.; Manners, I., Catalytic Dehydrocoupling/Dehydrogenation of N-Methylamine-Borane and AmmoniaBorane: Synthesis and Characterization of High Molecular Weight Polyaminoboranes. J. Am. Chem. Soc. 2010, 132 (38), 13332-13345.

9. Kumar, A.; Johnson, H. C.; Hooper, T. N.; Weller, A. S.; Algarra, A. G.; Macgregor, S. A., Multiple metal-bound oligomers from Ir-catalysed dehydropolymerisation of $\mathrm{H}_{3} \mathrm{~B} \cdot \mathrm{NH}_{3}$ as probed by experiment and computation. Chem. Sci. 2014, 5 (6), 2546-2553.

10. Paul, U. S. D.; Braunschweig, H.; Radius, U., Iridium-catalysed dehydrocoupling of aryl phosphine-borane adducts: synthesis and characterisation of high molecular weight poly(phosphinoboranes). Chem. Commun. 2016, 52 (55), 8573-8576.

11. Marziale, A. N.; Friedrich, A.; Klopsch, I.; Drees, M.; Celinski, V. R.; Schmedt auf der Günne, J.; Schneider, S., The Mechanism of Borane-Amine Dehydrocoupling with Bifunctional Ruthenium Catalysts. J. Am. Chem. Soc. 2013, 135 (36), 1334213355.

12. Burck, S.; Gudat, D.; Nieger, M., Diphosphanes with Polarized and Highly Reactive P-P Bonds. Angew. Chem. Int. Ed. 2004, 43 (36), 4801-4804. 
13. Dodds, D. L.; Haddow, M. F.; Orpen, A. G.; Pringle, P. G.; Woodward, G., Stereospecific Diphosphination of Activated Acetylenes: A General Route to Backbone-Functionalized, Chelating 1,2-Diphosphinoethenes. Organometallics 2006, 25 (25), 5937-5945.

14. Burck, S.; Götz, K.; Kaupp, M.; Nieger, M.; Weber, J.; Schmedt auf der Günne, J.; Gudat, D., Diphosphines with Strongly Polarized P-P Bonds: Hybrids between Covalent Molecules and Donor-Acceptor Adducts with Flexible Molecular Structures. J. Am. Chem. Soc. 2009, 131 (30), 10763-10774.

15. Giffin, N. A.; Hendsbee, A. D.; Roemmele, T. L.; Lumsden, M. D.; Pye, C. C.; Masuda, J. D., Preparation of a Diphosphine with Persistent Phosphinyl Radical Character in Solution: Characterization, Reactivity with $\mathrm{O}_{2}, \mathrm{~S}_{8}, \mathrm{Se}, \mathrm{Te}$, and $\mathrm{P}_{4}$, and Electronic Structure Calculations. Inorg. Chem. 2012, 51 (21), 11837-11850.

16. Szynkiewicz, N.; Ponikiewski, Ł.; Grubba, R., Symmetrical and unsymmetrical diphosphanes with diversified alkyl, aryl, and amino substituents. Dalton Transactions 2018, 47 (47), 16885-16894.

17. Bresien, J.; Pilopp, Y.; Schulz, A.; Szych, L. S.; Villinger, A.; Wustrack, R., Synthesis of Sterically Demanding Secondary Phosphides and Diphosphanes and Their Utilization in Small-Molecule Activation. Inorg. Chem. 2020, 59 (18), 1356113571.

18. Issleib, K.; Seidel, W., Darstellung und chemisches Verhalten aliphatischer und cycloaliphatischer Diphosphine, $\mathrm{R}_{2} \mathrm{P}-\mathrm{PR}_{2}$. Chem. Ber. 1959, 92 (11), 2681-2694.

19. Nöth, H.; Vetter, H.-J., Dialkylamino-phosphane, I. Darstellung und Eigenschaften von Tetrakis(dimethylamino)-diphosphan und Pentakis(dimethylamino)-triphosphan. Chem. Ber. 1961, 94 (6), 1505-1516.

20. Niebergall, H.; Langenfeld, B., Synthese von Tetraorgano-diphosphinen, Diorgano-phosphinen und Tetraorgano-diphosphindisulfiden.Chem. Ber. 1962, 95 (1), 64-76.

21. Henderson, W. A.; Epstein, M.; Seichter, F. S., Some Aspects of the Chemistry of Cyclopolyphosphines. J. Am. Chem. Soc. 1963, 85 (16), 2462-2466.

22. Dörken, C., Ueber Derivate des Diphynylphosphor-chlorürs und des Diphenylphosphins. Ber. d. Dt. Chem. Ges. 1888, 21 (1), 1505-1515.

23. Issleib, K.; Krech, K., Alkali-Phosphorverbindungen und ihr reaktives Verhalten, XXXI: Unsymmetrische Biphosphine des Typs $\mathrm{R}_{2} \mathrm{P}-\mathrm{PR}_{2}^{\prime}$. Chem. Ber. 1965, 98 (4), 1093-1096.

24. Dodds, D. L.; Floure, J.; Garland, M.; Haddow, M. F.; Leonard, T. R.; McMullin, C. L.; Orpen, A. G.; Pringle, P. G., Diphosphanes derived from phobane and phosphatrioxa-adamantane: similarities, differences and anomalies. Dalton Trans. 2011, 40 (27), 7137-7146.

25. Molitor, S.; Becker, J.; Gessner, V. H., Selective Dehydrocoupling of Phosphines by Lithium Chloride Carbenoids. J. Am. Chem. Soc. 2014, 136 (44), 15517-15520.

26. Schneider, H.; Schmidt, D.; Radius, U., The reductive P-P coupling of primary and secondary phosphines mediated by $\mathrm{N}$-heterocyclic carbenes. Chem. Commun. 2015, 51 (50), 10138-10141. 
27. Schwedtmann, K.; Schoemaker, R.; Hennersdorf, F.; Bauzá, A.; Frontera, A.; Weiss, R.; Weigand, J. J., Cationic 5-phosphonio-substituted N-heterocyclic carbenes. Dalton Trans. 2016, 45 (28), 11384-11396.

28. Fritz, G., Advances in Inorg. Chem. Academic Press 1987.

29. Feldmann, K.-O.; Weigand, J. J., P-N/P-P Bond Metathesis for the Synthesis of Complex Polyphosphanes. J. Am. Chem. Soc. 2012, 134 (37), 15443-15456.

30. Masuda, J. D.; Hoskin, A. J.; Graham, T. W.; Beddie, C.; Fermin, M. C.; Etkin, N.; Stephan, D. W., Catalytic PH Activation by Ti and Zr Catalysts. Chem. Eur. J. 2006, 12 (34), 8696-8707.

31. King, A. K.; Buchard, A.; Mahon, M. F.; Webster, R. L., Facile, Catalytic Dehydrocoupling of Phosphines Using $\beta$-Diketiminate Iron(II) Complexes. Chem. Eur. J. 2015, 21 (45), 15960-15963.

32. Böhm, V. P. W.; Brookhart, M., Dehydrocoupling of Phosphanes Catalyzed by a Rhodium(I) Complex. Angew. Chem. Int. Ed. 2001, 40 (24), 4694-4696.

33. Waterman, R., Dehydrogenative Bond-Forming Catalysis Involving Phosphines: Updated Through 2010. Curr. Org. Chem. 2012, 16 (10), 1313-1331.

34. Wu, L.; Annibale, V. T.; Jiao, H.; Brookfield, A.; Collison, D.; Manners, I., Homoand heterodehydrocoupling of phosphines mediated by alkali metal catalysts. Nat. Comm. 2019, 10 (1), 2786.

35. Schaffrath, M.; Villinger, A.; Michalik, D.; Rosenthal, U.; Schulz, A., TitanoceneMediated Formation of Phosphorus-Phosphorus Bonds. Organometallics 2008, 27 (7), 1393-1398.

36. Hinke, A.; Kuchen, W., Zur Kenntnis der Organophosphorverbindungen, XXII. 1,2-Diaryl-1,2-dibromdiphosphane. Chem. Ber. 1983, 116 (9), 3003-3010.

37. Weber, L., The chemistry of diphosphenes and their heavy congeners: synthesis, structure, and reactivity. Chem. Rev. 1992, 92 (8), 1839-1906.

38. Yoshifuji, M.; Shima, I.; Inamoto, N.; Hirotsu, K.; Higuchi, T., Synthesis and structure of bis(2,4,6-tri-tert-butylphenyl)diphosphene: isolation of a true phosphobenzene. J. Am. Chem. Soc. 1981, 103 (15), 4587-4589.

39. Shah, S.; Simpson, M. C.; Smith, R. C.; Protasiewicz, J. D., Three Different Fates for Phosphinidenes Generated by Photocleavage of Phospha-Wittig Reagents $\mathrm{ArPPMe}_{3}$. J. Am. Chem. Soc. 2001, 123 (28), 6925-6926.

40. Eilrich, V. J.; Hey-Hawkins, E., Cyclooligophosphanes and their coordination chemistry. Coord. Chem. Rev. 2021, 437, 213749.

41. Wellnitz, T.; Hering-Junghans, C., Synthesis and Reactivity of Monocyclic Homoleptic Oligophosphanes. Eur. J. Inorg. Chem. 2021, 2021 (1), 8-21.

42. Schumann, A.; Reiß, F.; Jiao, H.; Rabeah, J.; Siewert, J.-E.; Krummenacher, l.; Braunschweig, H.; Hering-Junghans, $\mathrm{C}$., A selective route to aryl-triphosphiranes and their titanocene-induced fragmentation. Chem. Sci. 2019, 10 (34), 78597867.

43. Appel, R.; Schöler, H., Notiz über ein bequemes Verfahren zur Darstellung von Dichlorphosphoranen. Chem. Ber. 1977, 110 (6), 2382-2384.

44. Frazier, S. E.; Nielsen, R. P.; Sisler, H. H., Reactions of Some Chlorophosphines with Tributylphosphine. Inorg. Chem. 1964, 3 (2), 292-294. 
45. Spangenberg, S. F.; Sisler, H. H., Reactions of some tri-n-alkylphosphines with some chlorophosphines. Inorg. Chem. 1969, 8 (4), 1006-1010.

46. Summers, J. C.; Sisler, H. H., Reactions of some trialkyls of phosphorus, arsenic, or antimony with some organohalophosphines, -arsines, or -stibines. Inorg. Chem. 1970, 9 (4), 862-869.

47. M. Godfrey, S.; A. McAuliffe, C.; Mushtaq, I.; G. Pritchard, R.; M. Sheffield, J., The structure of $\mathrm{R}_{3} \mathrm{PBr}_{2}$ compounds in the solid state and in solution; geometrical dependence on $\mathrm{R}$, the crystal structures of tetrahedral ionic $\mathrm{Et}_{3} \mathrm{PBr}_{2}$ and molecular trigonal bipyramidal $\left(\mathrm{C}_{6} \mathrm{~F}_{5}\right)_{3} \mathrm{PBr}_{2}$. J. Chem. Soc., Dalton Trans. 1998, (22), 3815-3818.

48. Nikitin, K.; Jennings, E. V.; Al Sulaimi, S.; Ortin, Y.; Gilheany, D. G., Dynamic CrossExchange in Halophosphonium Species: Direct Observation of Stereochemical Inversion in the Course of an $\mathrm{S}_{\mathrm{N}} 2$ Process. Angew. Chem. Int. Ed. 2018, 57 (6), 1480-1484.

49. Pyykkö, P.; Atsumi, M., Molecular Double-Bond Covalent Radii for Elements LiE112. Chem. Eur. J. 2009, 15 (46), 12770-12779.

50. Niecke, E.; Rüger, R., Tetrakis(trimethylsilyl)diaminodiphosphene. Angew. Chem. Int. Ed. Engl. 1983, 22 (2), 155-156.

51. Lauk, S.; Zimmer, M.; Morgenstern, B.; Huch, V.; Müller, C.; Sitzmann, H.; Schäfer, A., Tetra- and Pentaisopropylcyclopentadienyl Complexes of Group 15 Elements. Organometallics 2021, 40 (5), 618-626.

52. Ranaivonjatovo, H.; Escudié, J.; Couret, C.; Satgé, J., Dibisyldiphosphene: New routes and first aspects of its reactivity. Phosphorus, Sulfur Relat. Elem. 1987, 31 (1-2), 81-87.

53. Bard, A. J.; Cowley, A. H.; Kilduff, J. E.; Leland, J. K.; Norman, N. C.; Pakulski, M.; Heath, G. A., Notes. Oxidation and reduction of phosphorus-phosphorus and arsenic-arsenic double bonds. An electrochemical study of two diphosphenes and a diarsene. J. Chem. Soc., Dalton Trans. 1987, (1), 249-251.

54. Asami, S.-S.; Okamoto, M.; Suzuki, K.; Yamashita, M., A Boryl-Substituted Diphosphene: Synthesis, Structure, and Reaction with $n$-Butyllithium To Form a Stabilized Adduct by $\mathrm{p}_{\pi}-\mathrm{p}_{\pi}$ Interaction. Angew. Chem. Int. Ed. 2016, 55 (41), 12827-12831.

55. Dhara, D.; Kalita, P.; Mondal, S.; Narayanan, R. S.; Mote, K. R.; Huch, V.; Zimmer, M.; Yildiz, C. B.; Scheschkewitz, D.; Chandrasekhar, V.; Jana, A., Reactivity enhancement of a diphosphene by reversible $\mathrm{N}$-heterocyclic carbene coordination. Chem. Sci. 2018, 9 (18), 4235-4243.

56. Hayakawa, N.; Sadamori, K.; Tsujimoto, S.; Hatanaka, M.; Wakabayashi, T.; Matsuo, T., Cleavage of a $\mathrm{P}=\mathrm{P}$ Double Bond Mediated by $\mathrm{N}$-Heterocyclic Carbenes. Angew. Chem. Int. Ed. 2017, 56 (21), 5765-5769.

57. Krachko, T.; Slootweg, J. C., N-Heterocyclic Carbene-Phosphinidene Adducts: Synthesis, Properties, and Applications. Eur. J. Inorg. Chem. 2018, 2018 (24), 2734-2754.

58. Chitnis, S. S.; Robertson, A. P. M.; Burford, N.; Weigand, J. J.; Fischer, R., Synthesis and reactivity of cyclo-tetra(stibinophosphonium) tetracations: redox and 
coordination chemistry of phosphine-antimony complexes. Chem. Sci. 2015, 6 (4), 2559-2574.

59. Smith, R. C.; Shah, S.; Urnezius, E.; Protasiewicz, J. D., An Unusual Equilibrium Chlorine Atom Transfer Process and Its Potential for Assessment of Steric Pressure by Bulky Aryls. J. Am. Chem. Soc. 2003, 125 (1), 40-41. 